\title{
Biochemical characterization of the YBPCI miniprotein, the first carboxypeptidase inhibitor isolated from Yellow Bell Pepper (Capsicum annuum L). A novel contribution to the knowledge of miniproteins stability
}

\author{
Juliana Cotabarren $^{\mathrm{a}}$, Mariana Edith Tellechea ${ }^{\mathrm{a}}$, Francesc Xavier Avilés ${ }^{\mathrm{b}}$, Julia Lorenzo Rivera ${ }^{\mathrm{b}, * *}$, \\ Walter David Obregón ${ }^{\mathrm{a}, *}$ \\ ${ }^{a}$ Centro de Investigación de Proteínas Vegetales (CIPROVE), Departamento de Ciencias Biológicas, Facultad de Ciencias Exactas, Universidad Nacional de La Plata, 47 y \\ 115 S/N, B1900AVW, La Plata, Argentina \\ ${ }^{\mathrm{b}}$ Institut de Biotecnologia i de Biomedicina, Universitat Autònoma de Barcelona, Campus Universitari 08193, Bellaterra, Cerdanyola del Vallès, Barcelona, Spain
}

\section{A R T I C L E I N F O}

\section{Keywords:}

Carboxypeptidase inhibitor

Plant inhibitor

Capsicum annuum

Protease

Stable miniproteins

Gastrointestinal digestion

\begin{abstract}
A B S T R A C T
The cystine-knot metallocarboxypeptidase inhibitors (MCPIs) are peptides that contribute to control proteolytic activity, involved in storage, growth and maintenance of plants. Lately studies reported several MCPIs with potential use in biomedical applications; as anti-cancer, anti-thrombotic, anti-malaric and anti-angiogenic agents. We report the isolation, purification, chemical stability and biochemical characterization of a novel carboxypeptidase A inhibitor (YBPCI) isolated from Capsicum annuum L. var. Yellow Bell Pepper, the first cystine-knot miniprotein (CKM) of the species. We demonstrate the stability of YBPCI (IC50 $=0.90 \mu \mathrm{g} / \mathrm{ml}$ ) to high temperatures, high salt concentration and extreme $\mathrm{pH}$ values. MALDI-TOF/MS analysis detected a molecular weight of $4057 \mathrm{Da}$, and peptide mass fingerprint resulted in no matches with other protease inhibitors. In vitro gastrointestinal digestion subjecting YBPCI to $\mathrm{pH} 2$ incubation and proteolytic attack resulted in complete inhibitory activity. To summarize, there are no reports to date of carboxypeptidase inhibitors in $C$. annuum species, giving our report much more relevance.
\end{abstract}

\section{Introduction}

Carboxypeptidases (CPs) are enzymes that cleave proteins from the C-terminus, usually one residue at a time, playing an essential role in degradation, processing, and modulation of proteins and peptides [1]. CPs were initially considered as degrading enzymes associated with protein catabolism, but over the years evidence demonstrates that some CPs play key roles in controlling a vast variety of biological processes [2]. Among CPs, metallocarboxypeptidases (MCPs) are exopeptidases that hydrolyze the C-terminal amide bond by a zinc-dependent mechanism [3]. In humans, the dysregulated activity of some MCPs has been associated with several diseases such as blood coagulation/ fibrinolysis, inflammation, carcinogenesis, epilepsy and febrile seizures, among others $[1,2,4,5]$. According to these studies, the use of protease inhibitors (PIs) in order to regulate MCPs action has emerged as a potential tool for the development of therapeutic strategies for a large number of diseases; as anticarcinogenic, anti-angiogenic and antithrombotic, among others [6-9]. Furthermore, although protease inhibitors have been considered only as antinutritional factors, they have regained interest in recent years because of their potential for drug development and positive dietary effects.

The application of natural PIs offers great advantages over those of synthetic origin due to their lower toxicity and hydrophobicity [10]; however, naturally occurring metallocarboxypeptidase inhibitors

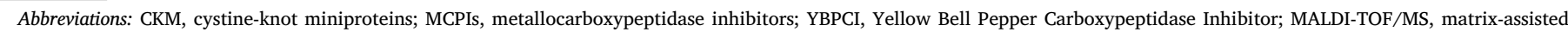

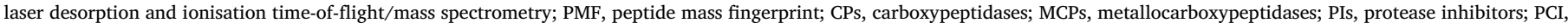

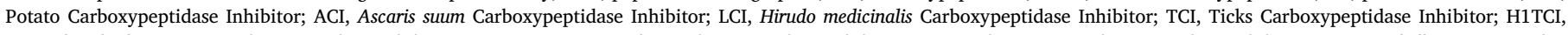

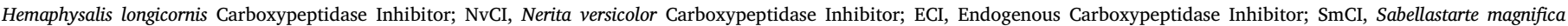

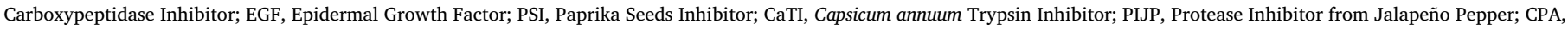

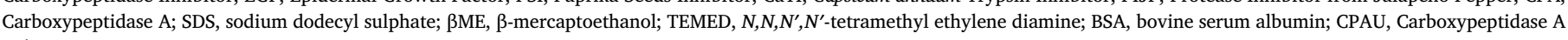
unit

* Corresponding author.

*** Corresponding author.

E-mail addresses: cotabarren.juliana@biol.unlp.edu.ar (J. Cotabarren), marianatellechea@biol.unlp.edu.ar (M.E. Tellechea), FrancescXavier.Aviles@uab.cat (F.X. Avilés), julia.lorenzo@uab.es (J. Lorenzo Rivera), davidobregon@biol.unlp.edu.ar (W.D. Obregón).
} 
(MCPIs) have only been identified in: Solanaceae family, such as potato (PCI) and its close homologue in tomato [11,12]; the intestinal parasite Ascaris suum (ACI) [13]; the medicinal leech Hirudo medicinalis (LCI) [14]; the tick Rhipicephalus bursa (TCI) [15] and Hemaphysalis longicornis (H1TCI) [16]; the marine mollusk Nerita versicolor (NvCI) [17]; in rat and human tissues (latexin or endogenous carboxypeptidase inhibitor (ECI)) [18] and in the marine ringworm Sabellastarte magnifica (SmCI) [19]. Moreover, the well-studied PCI had shown multiple bioactive functions: antitumor properties as an Epidermal Growth Factor (EGF) antagonist [6], antimalaric agent by the growth inhibition of the parasite Plasmodium falciparum [20], antithrombotic agent [7], and in vitro antifungal properties against phytopathogens were reported [21]. All of these MCPIs belong to the cystine knot or T-knot family, and share similar features such as their small size (39-75 residues) and stabilization by several disulphide bridges; typically comprising six Cys residues with conserved disulphide bonds. Despite the common knottin motif, knottin-type peptides have hypervariable sequences, differing by their amino acid sequences, the length between disulphide bonds, and the linear and cyclic nature of the peptide backbone [22]. Plant knottintype peptides, particularly the subfamily of cyclotides, have been reported to possess high thermal, chemical, and enzymatic stability [23]. Cyclotides are also resistant to gastrointestinal proteases like trypsin, chymotrypsin, pepsin, or elastase, and certain members of cyclotide family can even penetrate the intestinal mucosa excised from rats [24].

The genus Capsicum (vegetable pepper) was initially domesticated in Mexico, northern Central America and the Andean region of South America. By the end of the 20th century, Argentina was the main producer in South America of vegetable pepper with a cultivation of about nine thousand hectares of pepper per year, representing an approximate production of 300,000 tons. Capsicum varieties have different uses as food products, either as fresh or processed vegetables, spices or even medicines and pest control, which makes this crop of immense cultural and economic importance [25]. Capsicum annuum L. presents a large number of varieties depending on the characteristics of the fruit (elongated pepper, four hulls, chili vinegar, yellow pepper, orange, violet, among others) of which a few have been studied so far. Reports of protease inhibitors from $C$. annuum are limited to the serine proteinase type. PSI-1.1 and PSI-1.2 were isolated from paprika seeds [26], CaTI was isolated from chilli pepper seeds (UENF 1381) [27], CapA1 and CapA2 were isolated from C. annum var. Phule Jyoti leaves [28] and finally PIJP was isolated from jalapeño pepper [29], all of them presented inhibitory activity against trypsin and chymotrypsin. In this work, we isolated and characterized a carboxypeptidase inhibitor from C. annuum L. var. Yellow Bell Pepper named YBPCI. To our best knowledge, this is the first report of a metalloproteinase inhibitor isolated from C. annuum. Furthermore, we demonstrate that YBPCI displays resistance to in vitro gastrointestinal digestion, suggesting that PIs could reach the colon in intact form. These results encourage the study on possible pharmacological applications that may be present through the ingestion of these inhibitors, either for their potential antiparasitic or antibacterial action on pathogenic bacteria.

\section{Material and methods}

\subsection{Materials}

Carboxypeptidase A (CPA) from bovine pancreas, Pepsin from porcine gastric mucosa, Pancreatin from porcine pancreas, sodium chloride, tris (hydroxymethyl) aminomethane, sodium dodecyl sulphate (SDS), $\beta$-mercaptoethanol ( $\beta M E)$, Coomassie Blue G-250, $N, N, N^{\prime}, N^{\prime}$-tetramethyl ethylene diamine (TEMED) and bovine serum albumin were supplied by Sigma-Aldrich (U.S.A.). N-(4-methoxyphenylazoformyl)-phenylalanine-OH potassium salt was obtained from Bachem (Switzerland).

\subsection{Crude extract preparation}

C. annuum seeds were collected from nearby areas around La Plata (Argentina) and washed thoroughly in distilled water. The dry seeds ( $30 \mathrm{~g}$ ) were ground using a blender with addition of $3 \mathrm{vol}$ of $0.01 \mathrm{M}$ phosphate buffer, $0.1 \mathrm{M} \mathrm{NaCl}, \mathrm{pH} 7.4$. The mixture was incubated $3 \mathrm{~h}$ at $4{ }^{\circ} \mathrm{C}$ and filtered with gauze. The suspension was centrifuged at $7000 \mathrm{~g}$ for $30 \mathrm{~min}$ at $4{ }^{\circ} \mathrm{C}$, and the supernatant was collected and frozen at $-20{ }^{\circ} \mathrm{C}$ until analysis.

\subsection{Carboxypeptidase a inhibition activity}

The CPA activity assay is based on the hydrolysis of the substrate N(4-methoxyphenylazoformyl)-Phe-OH [30]. For the inhibition experiment a fixed concentration of CPA solution $(50 \mathrm{nM})$ was pre-incubated with different concentrations of inhibitor in $0.1 \mathrm{M}$ Tris-HCl buffer $(\mathrm{pH}$ 7.4) containing $0.2 \mathrm{M} \mathrm{NaCl}$. After $15 \mathrm{~min}$ at $37{ }^{\circ} \mathrm{C}$, the chromogenic substrate was added to the reaction mix at a concentration of $1 \mathrm{mM}$ and, immediately, the absorbance at $340 \mathrm{~nm}$ was measured every minute for a minimum of $15 \mathrm{~min}$. The protease inhibitor activity was expressed in terms of percent inhibition of CPA activity throughout the course of study, by using the comparison of absorbance changes of the test and the control, according to the equation:

CPA inhibition $(\%)=\left(1-\frac{[\Delta A b s(340 \mathrm{~nm}) / \Delta t(\mathrm{~min})]_{\text {Inhibitor }}}{[\Delta A b s(340 \mathrm{~nm}) / \Delta t(\min )]_{\text {Control }}}\right) \times 100$

Inhibitory activity (IA) was defined according to Tellechea et al. (2016) [31]. Measurements were carried out in triplicate.

\subsection{Protein estimation}

Protein concentration was measured by the Bradford's method using bovine serum albumin (BSA) as standard (0-1 mg/ml). $20 \mu \mathrm{l}$ of sample and standard were mixed with $200 \mu \mathrm{l}$ of reagent for $10 \mathrm{~min}$ at room temperature. Afterwards, protein concentration was measured by absorbance at $595 \mathrm{~nm}$ (Tecan Infinite M200 PRO).

\subsection{Purification}

\subsubsection{Partial purification by heat treatment}

$1 \mathrm{ml}$ of crude extract $(400 \mu \mathrm{g} / \mathrm{ml})$ was subjected to $60{ }^{\circ} \mathrm{C}, 70{ }^{\circ} \mathrm{C}$, $80{ }^{\circ} \mathrm{C}, 90{ }^{\circ} \mathrm{C}$ or $100{ }^{\circ} \mathrm{C}$ for $5 \mathrm{~min}$, thermally denatured proteins were removed by centrifugation $\left(10000 \mathrm{~g}, 40 \mathrm{~min}, 4^{\circ} \mathrm{C}\right) .100 \mu \mathrm{l}$ of each supernatant -including a crude extract control- was employed as sample in the CPA inhibitory activity assay and residual activity was determined as described previously.

\subsubsection{Affinity chromatography purification}

A sample of heat treated extract containing $200 \mu \mathrm{g} / \mathrm{ml}$ of protein was loaded to a carboxypeptidase A-glyoxyl-agarose column $(1.5 \times 10 \mathrm{~cm})$ [32] previously equilibrated with $0.1 \mathrm{M}$ Tris-HCl buffer (pH 8.0) containing $0.2 \mathrm{M} \mathrm{NaCl}$. In the first step unbound proteins were eluted with equilibration buffer, and then affiliated proteins were eluted with $\mathrm{HCl} \mathrm{pH} \mathrm{2.0.} \mathrm{The} \mathrm{eluent} \mathrm{was} \mathrm{adjusted} \mathrm{to} \mathrm{pH} 7.0$ and the fractions exhibiting inhibitory activity were pooled.

\subsection{Characterization of protease inhibitor}

\subsubsection{SDS-tricine-PAGE}

SDS-Tricine-PAGE was used to determine the purification advance of the protease inhibitor during purification. Samples were mixed with sample buffer (Tris $0.13 \mathrm{M}$, SDS $2 \%$, $\beta$-mercaptoethanol 5\% v/v, glycerol $8 \% \mathrm{v} / \mathrm{v}$, bromophenol blue $0.002 \% \mathrm{p} / \mathrm{v}, \mathrm{pH} 6.8$ ) and incubated 5 min at $100{ }^{\circ} \mathrm{C}$, then subjected to denaturing electrophoresis at a constant current of $15 \mathrm{~mA}$ per gel using a Mini - Protean III dual slab 
cell (Bio-Rad, Hercules, CA 94547, USA), using 4\% stacking gel and $12 \%$ separating gel. After electrophoresis the gels were stained with $0.2 \%$ Coomassie Brilliant Blue G-250 and destained with distilled water.

\subsubsection{Molecular mass determination by MALDI-TOF/MS}

Matrix-assisted laser desorption ionisation-time-of-flight mass spectrometry (MALDI-TOF/MS) was used for the determination of the inhibitor molecular mass, as well as its purity degree. MALDI-TOF mass spectra was acquired on a BRUKER Ultraflex spectrometer equipped with a pulsed nitrogen laser (337 $\mathrm{nm}$ ), in linear positive ion mode, using a $19 \mathrm{kV}$ acceleration voltage. Samples were prepared by mixing equal volumes of a saturated solution of matrix (3,5-dimethoxy-4-hydroxycinnamic acid-sinapinic acid) in $0.1 \%$ TFA in water/ACN 2:1, and $1 \mathrm{M}$ protein solution. From this mixture, $1 \mu \mathrm{l}$ was spotted on a sample slide (MP 384 Polished Steel, Bruker) and allowed to evaporate to dryness.

\subsubsection{Protein identification by $P M F$}

In-gel protein digestion was carried out using the In-Gel DigestZP Kit (MILLIPORE, Billerica, MA, USA). Pure protein band was excised with a scalpel, diced into $1 \mathrm{~mm}^{3}$ pieces and introduced into the wells, treated with $25 \mathrm{mM} \mathrm{NH} \mathrm{HCO}_{3} / 5 \%$ acetonitrile (ACN) and then with $25 \mathrm{mM} \mathrm{NH}_{4} \mathrm{HCO}_{3} / 50 \% \mathrm{ACN}$ (washing/destaining solutions) and finally dehydrated with pure ACN. Proteins were then reduced with $10 \mathrm{mM}$ DTT in buffer $25 \mathrm{mM} \mathrm{NH}_{4} \mathrm{HCO}_{3} / 5 \% \mathrm{ACN}$ for $1 \mathrm{~h}$ at room temperature. Cys sulphydryls were alkylated with $50 \mathrm{mM}$ iodoacetamide in $25 \mathrm{mM}$ $\mathrm{NH}_{4} \mathrm{HCO}_{3} / 5 \% \mathrm{ACN}$ for $1 \mathrm{~h}$ at $37^{\circ} \mathrm{C}$. Washing/destaining solutions were used for additional washing and finally, the gel pieces were dehydrated with pure ACN and then dried. Trypsin $(0.02 \mu \mathrm{g})$ in $25 \mathrm{mM} \mathrm{NH}_{4} \mathrm{HCO}_{3} /$ $5 \%$ ACN was added to rehydrate the gel pieces in each well and the digestion was carried out for $3 \mathrm{~h}$ at $37^{\circ} \mathrm{C}$. The tryptic peptides obtained were extracted from the gel with $0.2 \%$ TFA and captured on the C18 resin applying vacuum. Finally, the tryptic peptides were eluted with $50 \%$ ACN $/ 0.1 \%$ TFA.

MALDI-TOF/MS was used for protein identification by peptide mass fingerprint (PMF). Analysis was performed using an UltraFlex MALDITOF/MS mass spectrometer (Bruker Daltonics, Bremen, Germany). The sample was spotted on an AnchorChip target 160 and mixed with freshly prepared matrix solution $(10 \mathrm{mg} / \mathrm{ml}$ of a-cyano-4-hydroxycinnamic acid in aqueous solution containing $30 \%$ ACN and $0.1 \%$ TFA). External calibration was performed using peptide calibrants. Peptide masses were acquired with a range of ca. $800-4000 \mathrm{~m} / \mathrm{z}$. PMF spectra of samples analyzed were acquired and compared. Comprehensive peak assignments were accomplished using the BioTools software package (Bruker Daltonics).

\subsubsection{Effect of $p H$ on protease inhibitor stability}

The stability of protease inhibitor over extreme $\mathrm{pH}$ values was determined by evaluating the inhibitor activity at $\mathrm{pH} 7$ after incubating the heat-treated extract in different $\mathrm{pH}(2$ and 12$)$ for $1 \mathrm{~h}$, at $37^{\circ} \mathrm{C}$. After incubation, the reaction mixture was neutralized and assayed for protease inhibitor activity.

\subsubsection{Effect of $\mathrm{NaCl}$ concentration on protease inhibitor stability}

Effect of $\mathrm{NaCl}$ concentration on protease inhibitor stability was evaluated using sodium chloride at $0.5 \mathrm{M}$ and $2 \mathrm{M}$ concentrations in the reaction mixture. A ten times concentrated heat-treated extract sample was used to carry out $1 \mathrm{~h}$ incubation at $37^{\circ} \mathrm{C}$ with sodium chloride, and then $10 \mu \mathrm{l}$ of sample were assayed for protease inhibitory activity.

\subsubsection{In vitro simulation of gastrointestinal digestion}

In order to evaluate the effect of gastrointestinal digestion on protease inhibitor stability, an aliquot of $1 \mathrm{ml}$ of $100{ }^{\circ} \mathrm{C}$ treated extract $(200 \mu \mathrm{g} / \mathrm{ml})$ was subjected to gastric simulation. First the sample was adjusted to $\mathrm{pH} 2$ with $1 \mathrm{M} \mathrm{HCl}$, then pepsin (3400 IU/mg) was added on a rate of $182 \mathrm{IU}$ per mg of peptide and incubated 2 hs at $37{ }^{\circ} \mathrm{C}$ and $200 \mathrm{rpm}$. After incubation, sample was adjusted to $\mathrm{pH} 5.3$ with $0.5 \mathrm{M}$ $\mathrm{NaHCO}_{3}$ and then to $\mathrm{pH} 7.5$ with $2 \mathrm{M} \mathrm{NaOH}$. Pancreatin from porcine pancreas was added on a rate of $35 \mathrm{IU}$ per $\mathrm{mg}$ of peptide and incubated $3 \mathrm{hs}$ at $37^{\circ} \mathrm{C}$ and $200 \mathrm{rpm}$. Finally, the reaction was stopped by heating at $100{ }^{\circ} \mathrm{C}$ for $10 \mathrm{~min}$ and assayed for protease inhibitory activity.

\section{Results and discussion}

\subsection{Isolation of carboxypeptidase a inhibitor from Yellow Bell Pepper seeds}

MCPIs have been identified in Solanacea members such as potato and tomato, nevertheless there are no reports to date of MCPIs from Capsicum annuum members. In order to isolate a novel CPA inhibitor, crude extract preparation was achieved by pulverizing Yellow Bell Pepper (Capsicum annuum L.) seeds with addition of phosphate buffer, posterior incubation and centrifugation. Protein concentration determined by Bradford's method using a BSA $(0-1 \mathrm{mg} / \mathrm{ml})$ calibration curve resulted in $400 \mu \mathrm{g} / \mathrm{ml}$. Inhibitory activity was detected through kinetic measurements employing a simple microplate method [31]. If we define a CPA unit (CPAU) as the amount of enzyme required to produce 0.01 absorbance units diminution at $340 \mathrm{~nm}$ per minute, employing N-(4-methoxyphenilazoformyl)-Phe-OH as substrate at $37{ }^{\circ} \mathrm{C}$ and $\mathrm{pH} 7.4$, then we observe $0.76 \mathrm{CPAU}$ for the control curve without inhibitor, and $0.42 \mathrm{CPAU}$ with crude extract addition. Thus, the crude extract presents a $45 \%$ CPA inhibition.

\subsection{Purification of carboxypeptidase a inhibitor from Yellow Bell Pepper}

\subsubsection{Partial purification by heat treatment}

3.2.1.1. Carboxypeptidase a inhibition activity. Previous studies suggest PIs are heat-stable molecules due to disulfide bonds that stabilize their structure. Based on these results, we proposed a simple and rapid purification method that consisted in evaluation of the inhibitory activity after treating the crude extract to different temperatures. We observe that treatment at $80{ }^{\circ} \mathrm{C}$ during 5 min yields a product with higher activity than treatment at $60{ }^{\circ} \mathrm{C}$. Surprisingly, treatment at $100{ }^{\circ} \mathrm{C}$ gives a product with inhibitory activity as high as treatment at $80^{\circ} \mathrm{C}$ (Fig. 1), which indicates that the carboxypeptidase inhibitor from Yellow Bell Pepper is a very stable molecule. Although PIs are heatstable molecules, we found no reports on MCPIs with resistance to $100{ }^{\circ} \mathrm{C}$, such thermal treatment usually produce a reduction on inhibitory activity. In this case we are in presence of an unpublished result; the $100{ }^{\circ} \mathrm{C}$ treatment results in an inhibitory activity equal to the observed at $80{ }^{\circ} \mathrm{C}$, opening new insights in PIs stability.

As observed in Fig. 1, the CPA inhibitory activity is not only

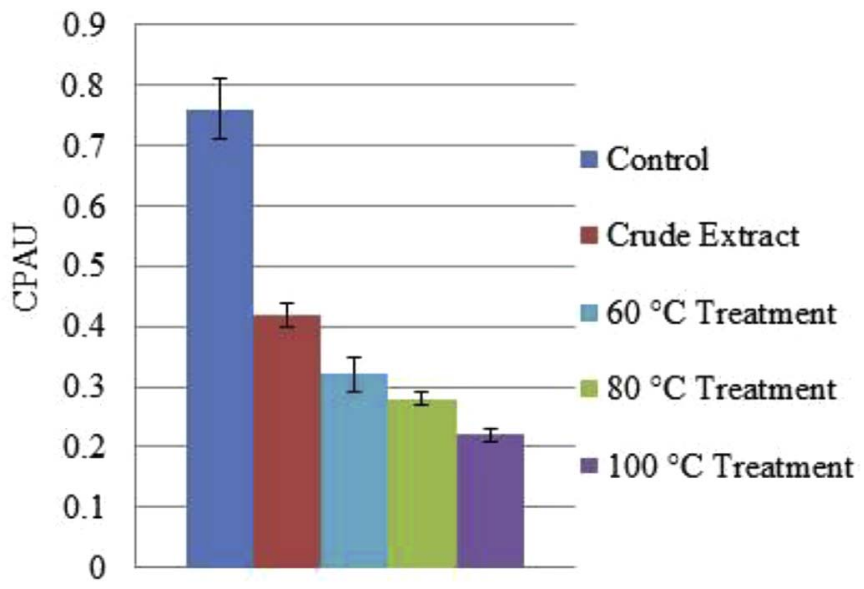

Fig. 1. Effect of heat treatment at different temperatures on the Carboxypeptidase A inhibitory activity. Error bar indicates standard deviation from triplicate determination. 


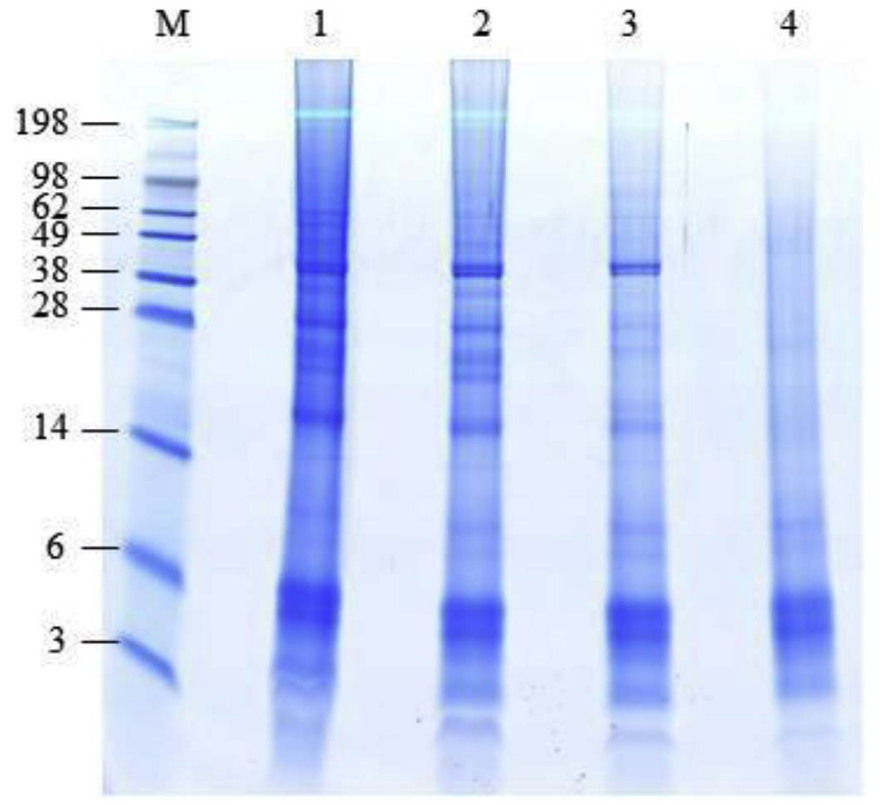

Fig. 2. Sodium dodecyl sulphate polyacrylamide gel electrophoresis (SDS-PAGE) for fractions corresponding to different heat treatments. $\mathrm{M}$, molecular weight standard $(\mathrm{kDa})$; 1: Crude extract; 2: $60{ }^{\circ} \mathrm{C}$ treated fraction; 3: $80{ }^{\circ} \mathrm{C}$ treated fraction; $4: 100{ }^{\circ} \mathrm{C}$ treated fraction.

maintained with temperature increase; it also increment gradually to the different thermal treatments. It is expected that, due to the great stability of these inhibitors, the same inhibitory activity observed in the crude extract will be maintained after thermal treatments. However, in this case the inhibitory activity presents a considerable increase. This would indicate the presence in the crude extract of CPA activating biomolecules that are affected by the thermal treatments, the presence of thermolabile biomolecules that reversibly inactivate the CPA inhibitor (YBPCI), or the possibility that in crude extract the inhibitor is in an inactivated isoform that is reverted by thermal treatment [33-36].

3.2.1.2. Protein pattern by SDS-PAGE. Proteins from each purification step were separated under reducing conditions and stained with Coomassie Blue after electrophoresis (Fig. 2). Based on the protein patterns we observe that the crude extract contains a variety of protein with different molecular weight. Heat treatment at $60{ }^{\circ} \mathrm{C}$ produces no significant changes in protein levels. Proteins with molecular weight around 20 and $30 \mathrm{kDa}$ and proteins with molecular weight higher than $60 \mathrm{kDa}$ were largely removed by incubation at $80{ }^{\circ} \mathrm{C}$. After heat treatment at $100{ }^{\circ} \mathrm{C}$, total removal of proteins with molecular weight over $6 \mathrm{kDa}$ is achieved [37], suggesting that those proteins that disappeared with the heating process are presumed to be heat labile proteins. These results, in addition to the elevated inhibitory activity of the treatment at $100{ }^{\circ} \mathrm{C}$ agree with previous studies that indicate PIs are heat-stable molecules. In this particular case, $100{ }^{\circ} \mathrm{C}$ treatment is proposed as a first purification step because it removes high protein proportion that remained intact in $80{ }^{\circ} \mathrm{C}$ treatment (as observed in Fig. 2) preserving carboxypeptidase inhibitory activity.

\subsubsection{Affinity chromatography purification}

Heat-treated extract was further purified by affinity chromatography using matrices specially designed by immobilization of carboxypeptidase A in glyoxyl agarose gel [32]. This methodology allows high specific purification based on molecular interaction between the CPA-glyoxyl agarose matrix and the CPA inhibitor resulting in elevated yield. The heat treatment was performed in order to obtain a partially purified preparation which shows a 85\% yield, while the affinity chromatography allows us to obtain a 11.5 -fold purification with respect to the crude extract with $28 \%$ yield in the eluted fraction (Table 1).

\subsection{Characterization of carboxypeptidase a inhibitor from Yellow Bell Pepper (YBPCI)}

\subsubsection{Characterization of partially purified YBPCI}

3.3.1.1. Dose-response curve of partially purified YBPCI. A dose-response curve was performed to determine the potency of inhibition of carboxypeptidase A, and IC50 values were calculated according to Tellechea et al. (2016) [31] (Fig. 3A.). The heat treatment at $100{ }^{\circ} \mathrm{C}$ of the extract from Yellow Bell Pepper produces an IC50 value of $6.7 \mu \mathrm{g} /$ $\mathrm{ml}$ in accordance to remotion of heat labile proteins, which results in a higher specific inhibitory activity.

3.3.1.2. Effect of $p H$ on stability of partially purified YBPCI. At extreme $\mathrm{pH}$ values, strong intramolecular electrostatic repulsion caused by high net charge results in swelling and unfolding of the protein molecules [38]. Intramolecular disulphide bridges are presumably responsible for the functional stability of some PIs in the presence of various physical and chemical denaturants [39], such as $\mathrm{pH}$, temperature, and reducing agents. The $\mathrm{pH}$ stability of $100{ }^{\circ} \mathrm{C}$ treated extract was investigated by incubation at extreme $\mathrm{pH}$ values (Fig. 4A.). The partially purified YBPCI shows high stability at extreme $\mathrm{pH}$ values, being slightly more stable at pH 2. Similar results have been reported for Solanum trypsin inhibitors [27], but there is no published data referred to $\mathrm{pH}$ stability of CPA inhibitors therefore we present the first study on pH stability of MCPIs.

3.3.1.3. Effect of salt on stability of protease inhibitor. The effect of $\mathrm{NaCl}$ on the inhibitory activity of $100{ }^{\circ} \mathrm{C}$ treated extract is depicted in Fig. 4B. No marked changes in the inhibitory activity were found when $\mathrm{NaCl}$ was added at $0.5 \mathrm{M}$ and $2 \mathrm{M}$ concentrations. From the result, the partially purified YBPCI shows high salt stability, representing a new proof of the molecule's great stability.

3.3.1.4. Effect of gastrointestinal digestion on stability of protease inhibitor. It has been recognized that dietary proteins and peptides are susceptible to hydrolysis during the different stages of gastrointestinal digestion, namely ingestion, digestion and absorption [40]. Once ingested, these proteins and peptides are subjected to hydrolysis by different enzymes present in the gastrointestinal tract such as pepsin, trypsin, chymotrypsin and peptidases at the surface of epithelial cells to release peptides of various lengths [41]. Some of these peptides may exert a direct function at the gastrointestinal tract. However, other peptides can be absorbed to reach target organs and tissues through systemic circulation [42].

In order to examine the effect of gastrointestinal proteases on YBPCI

Table 1

Purification of CPA inhibitor from Yellow Bell Pepper.

\begin{tabular}{|c|c|c|c|c|c|c|c|}
\hline Purification step & $\begin{array}{l}\text { Total protein } \\
\text { amount (mg) }\end{array}$ & $\begin{array}{l}\text { Protein concentration }(\mu \mathrm{g} / \\
\mathrm{ml})\end{array}$ & $\begin{array}{l}\mathrm{IC} 50(\mu \mathrm{g} / \\
\mathrm{ml})\end{array}$ & $\begin{array}{l}\text { Total Inhibitory activity, } \\
\text { IA (mU) }\end{array}$ & $\begin{array}{l}\text { Specific inhibitory activity, IA } \\
(\mathrm{mU} / \mathrm{mg})\end{array}$ & $\begin{array}{l}\text { Purity } \\
\text { (fold) }\end{array}$ & Yield (\%) \\
\hline Extract & 40 & 400 & 46.4 & 756 & 19 & 1 & 100 \\
\hline $100^{\circ} \mathrm{C}$ Treatment & 5 & 200 & 6.7 & 647 & 129 & 6.8 & 85 \\
\hline Afinity Cromatography & 1 & 16 & 0.9 & 218 & 218 & 11.5 & 28 \\
\hline
\end{tabular}



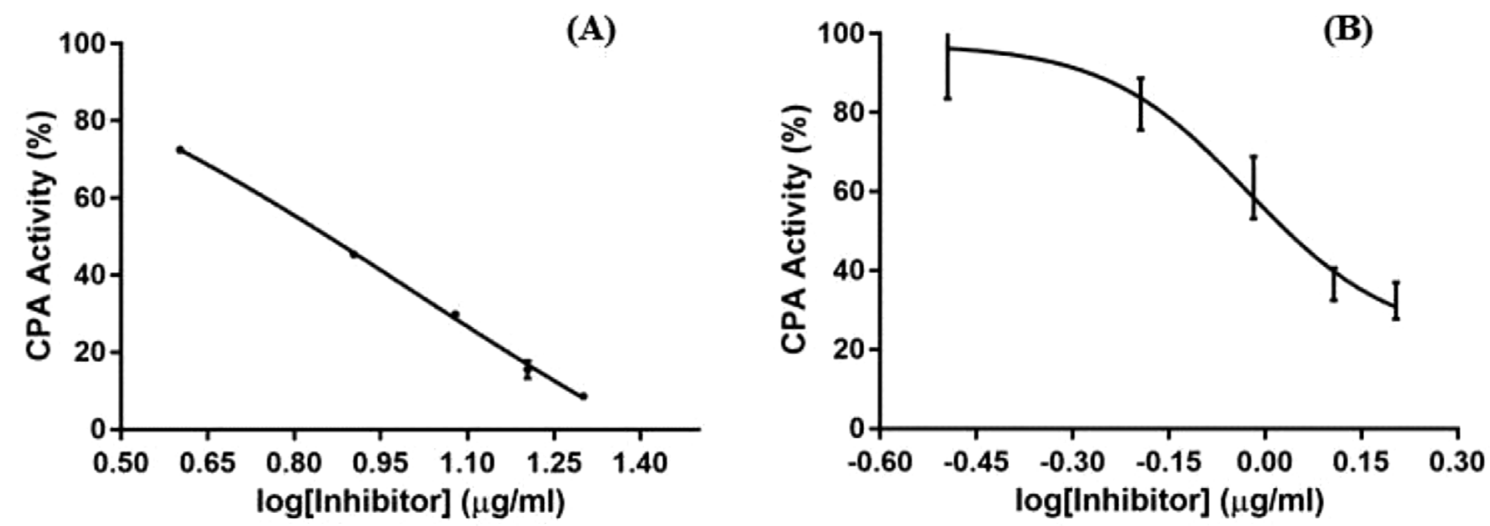

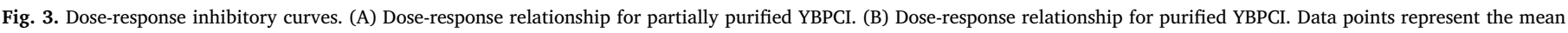
value of three determinations.

stability, digestion with pepsin and pancreatin was carried out according to Hernández-Ledesma et al. (2007) [43] (Fig. 4C.). The $100{ }^{\circ} \mathrm{C}$ treatment shows fully inhibitory activity after gastric simulation, suggesting that YBPCI reaches the colon in intact form. Experiments with cystine-knot miniproteins [44] and the Bowman-Birk Inhibitor [45] showed that these molecules enters the circulation through intestinal epithelial cells or the paracellular mechanism, opening new perspectives on potential clinical applications for oral administration of IPs.

In our work, we demonstrate the stability of partially purified YBPCI towards gastrointestinal digestion, through kinetic inhibition assays and dose-response curves on digested YBPCI. Even though in vitro gastrointestinal digestion has been assayed on other cystine-knot

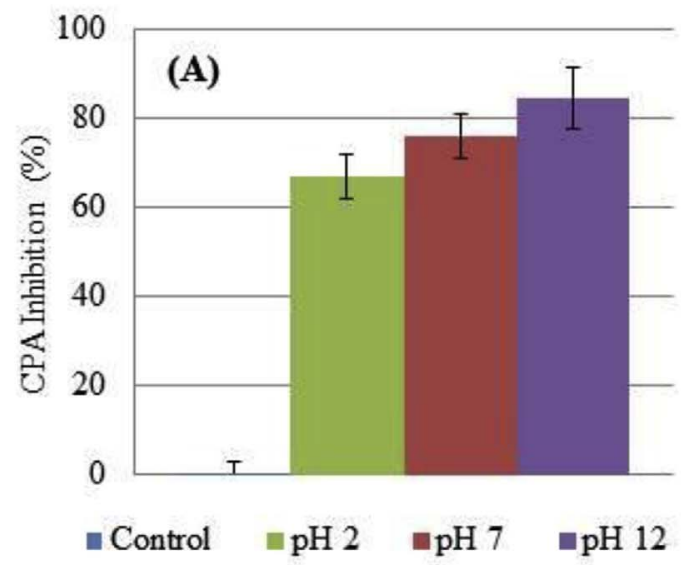

miniprotein [44], our work represents the first evidence of intact inhibitory activity of a cystine-knot miniprotein after gastric simulation, contributing to the understanding of IP's stability.

\subsubsection{Characterization of purified YBPCI}

3.3.2.1. Molecular mass determination. The molecular mass of the protease inhibitor purified by affinity chromatography was estimated based on SDS-PAGE analysis (about $4 \mathrm{kDa}$ ) (data not shown). Matrixassisted laser desorption ionisation-time-of-flight mass spectrometry (MALDI-TOF/MS) was used for the determination of the inhibitor molecular mass (Fig. 5.). Thus, the molecular weight is confirmed and precisely determined (4057 Da) of the order of the masses of

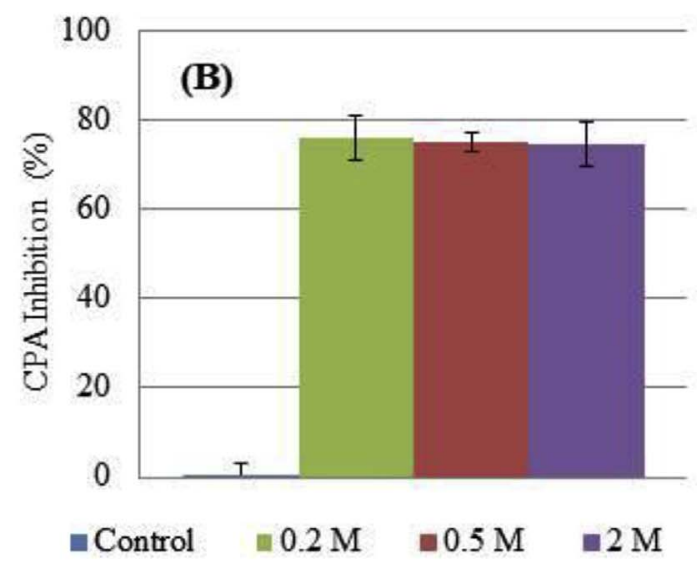

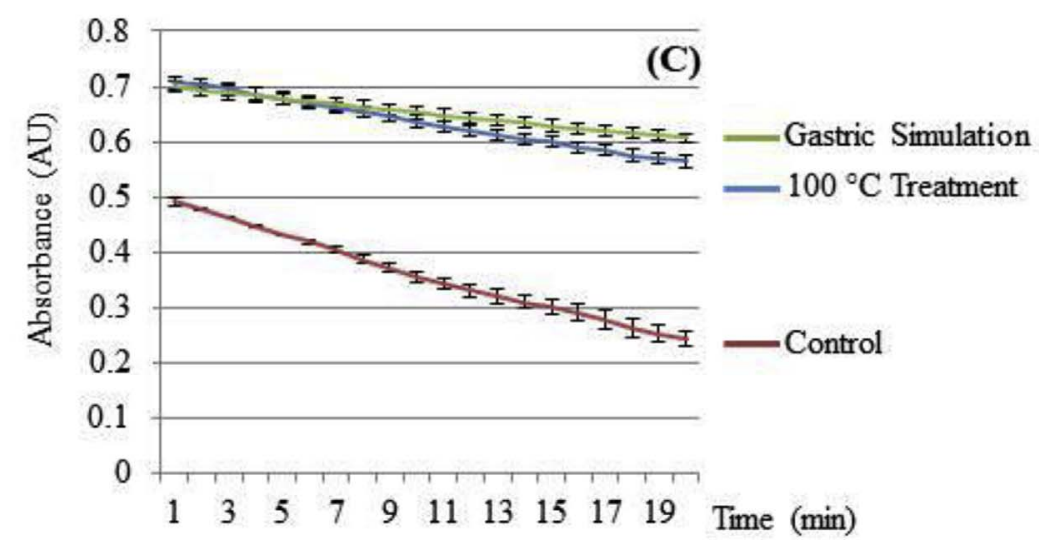

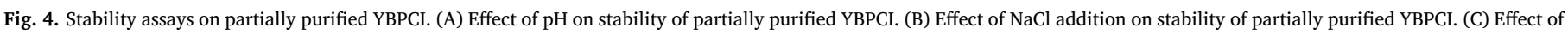
gastric simulation on stability of partially purified YBPCI. Error bar indicates standard deviation from triplicate determination. 


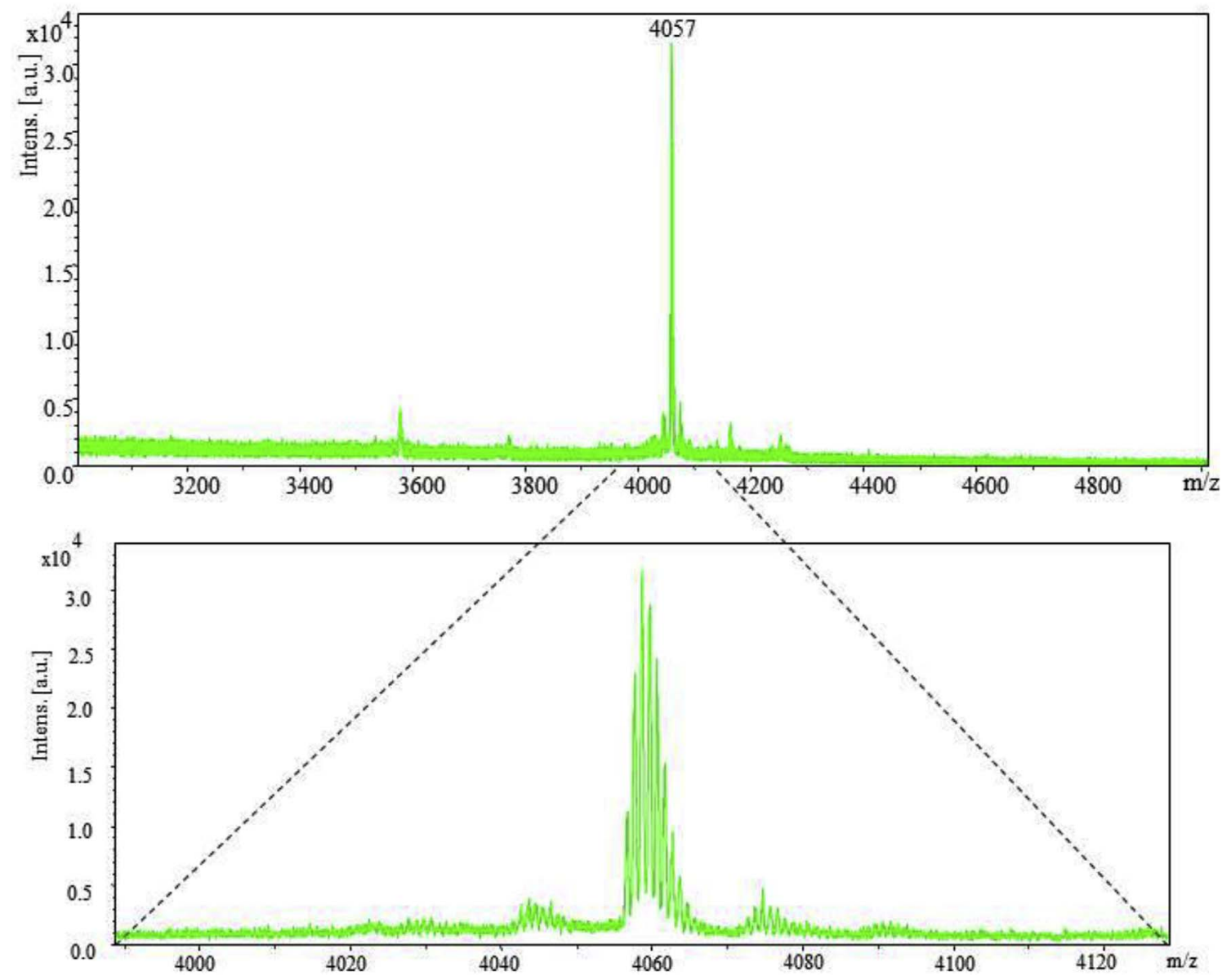

Fig. 5. MALDI-TOF MS spectra of recovered $\mathrm{m} / \mathrm{z}$ signal after elution of the inhibitor.

carboxypeptidase inhibitors already studied (imaPCI: 4234 Da, [12]; PCI: 4295 Da, [11]; NvCI: 5945 Da, [17]; LCI: 7326 Da, [14]; ACI: 7724 Da, [13]; TCI: 7935 Da, [15]; H1TCI: 8400 Da [16]).

3.3.2.2. Protein identification. Trypsin digestion of the inhibitor was analyzed by MALDI-TOF MS. MASCOT search tool (URL http://www. matrixscience.com) was used for identification of tryptic maps. The range of molecular weighs employed for the analysis of peptide mass fingerprint (PMF) of tryptic digested peptides from YBPCI, was between $1000 \mathrm{Da}$ and $4000 \mathrm{Da}$. No matches are found with other plant inhibitor which confirms the unique nature of the YBPCI and represents the first MCPI isolated from Capsicum annuum. Protein identification and differentiation by PMF has been adopted in our group as an excellent tool to differentiate, in fast and unequivocal way, proteases and protease inhibitors with very similar physicochemical and functional properties [32].

3.3.2.3. Dose-response curve of purified YBPCI. A dose-response curve was performed to determine the potency of inhibition of carboxypeptidase A, and IC50 value was calculated according to Tellechea et al. (2016) [31] (Fig. 3B.). The purified YBPCI produces an IC50 value of $0.9 \mu \mathrm{g} / \mathrm{ml}$, which results in a higher specific inhibitory activity than partially purified YBPCI.

\section{Conclusion}

The discovery of natural protease inhibitors is becoming more important to food and medicinal scientists. Herein, we report the first metalloproteinase inhibitor isolated from Capsicum annuum, a worldclass vegetable, and demonstrate the stability of the inhibitor to high temperatures, salt concentration and extreme $\mathrm{pH}$ values. Although this characteristic has been studied in other T-knot peptides, mostly on cyclotides of other mechanistic type, the results from the present research represents the first published study on stable miniproteins MCPItype. Also, it is the first report on gastrointestinal digestion stability of these molecules, suggesting that PIs could reach the colon in intact form, and encouraging the study of possible pharmaceutical applications as natural anti-parasitic and/or anti-bacterial formulations. Our work contributes to the understanding of IP's stability, representing the first demonstration of a cystine-knot miniprotein that conserves intact inhibitory activity after in-vitro gastrointestinal digestion.

Based on previous research that demonstrate some PIs reach systemic circulation through intestinal epithelial cells or the paracellular mechanism, the development of organic formulations or the controlled ingest of MCPIs-rich vegetables could represent a natural strategy for the treatment of multiple pathologies; angiogenesis, thrombosis, cancer, malaria, parasites. Also it could represent a natural way of health control in general population. To ascertain whether dietary consumption of MCPIs-rich foods is compatible with biological activity of these miniproteins in vivo as we found in vitro requires further and specific experimental evaluation.

\section{Acknowledgments}

This study forms part of the DSc degree thesis of J. Cotabarren, which was carried out at the UNLP. J. Cotabarren and M. Tellechea are doctoral fellows from UNLP and W.D. Obregón is a member of the Researcher Career Program of the Argentine Council of Scientific and Technical Research (CONICET). The authors acknowledge support of the Ministerio de Economía y Competitividad (MINECO) of Spain 
(project BIO2013-44973-R), CONICET (PIP 0120), Universidad Nacional de La Plata (UNLP, PPID X/014) and Bilateral Cooperation Program MinCyT-MICINN (project ES/09/24-AR2009/006). Mass spectrometry analyses were carried out in SePBioEs, the Proteomics facility from UAB, Barcelona, Spain. The authors also thank I. M. Cotabarren for the English revision of this paper.

\section{References}

[1] J.L. Arolas, J. Vendrell, F.X. Aviles, L.D. Fricker, Metallocarboxypeptidases: emerging drug targets in biomedicine, Curr. Pharm. Des. 13 (2007) 349-366.

[2] S. Tanco, J. Lorenzo, J. Garcia-Pardo, S. Degroeve, L. Martens, F.X. Aviles, K. Gevaert, P. Van Damme, Proteome-derived peptide libraries to study the substrate specificity profiles of carboxypeptidases, Mol. Cell. Proteomics 12 (2013) 2096-2110, http://dx.doi.org/10.1074/mcp.M112.023234.

[3] D. Fernandez, I. Pallares, G. Covaleda, F.X.A., J. Vendrell, Metallocarboxypeptidases and their inhibitors: recent developments in biomedically relevant protein and organic ligands, Curr. Med. Chem. 20 (2013) 1595-1608, http://dx.doi.org/10.2174/0929867311320120009.

[4] M.R. Sapio, A. Salzmann, M. Vessaz, A. Crespel, P.J. Lyons, A. Malafosse, L.D. Fricker, Naturally occurring carboxypeptidase A6 mutations: effect on enzyme function and association with epilepsy, J. Biol. Chem. 287 (2012) 42900-42909, http://dx.doi.org/10.1074/jbc.M112.414094.

[5] L. Sun, J. Burnett, C. Guo, Y. Xie, J. Pan, Z. Yang, Y. Ran, D. Sun, CPA4 is a promising diagnostic serum biomarker for pancreatic cancer, Am. J. Cancer Res. 6 (2016) 91-96 http://www.ncbi.nlm.nih.gov/pmc/articles/PMC4759400/.

[6] M. Sitjà-Arnau, M.A. Molina, C. Blanco-Aparicio, L. Ferrer-Soler, J. Lorenzo, F.X. Avilés, E. Querol, R. De Llorens, Mechanism of action of potato carboxypeptidase inhibitor (PCI) as an EGF blocker, Cancer Lett. 226 (2005) 169-184, http://dx.doi.org/10.1016/j.canlet.2005.01.025.

[7] X. Wang, P.L. Smith, M.Y. Hsu, M.L. Ogletree, W.A. Schumacher, Murine model of ferric chloride-induced vena cava thrombosis: evidence for effect of potato carboxypeptidase inhibitor, J. Thromb. Haemost. 4 (2006) 403-410, http://dx.doi org/10.1111/j.1538-7836.2006.01703.x.

[8] C. Cavallini, M. Trettene, M. Degan, P. Delva, B. Molesini, P. Minuz, T. Pandolfini, Anti-angiogenic effects of two cystine-knot miniproteins from tomato fruit, $\mathrm{Br}$. J. Pharmacol. 162 (2011) 1261-1273, http://dx.doi.org/10.1111/j.1476-5381.2010. 01154.X.

[9] Z. Xue, Y. Zhou, C. Wang, J. Zheng, P. Zhang, L. Zhou, L. Wu, Y. Shan, M. Ye, Y. He, Z. Cai, Latexin exhibits tumor-suppressor potential in pancreatic ductal adenocarcinoma, Oncol. Rep. 35 (2016) 50-58, http://dx.doi.org/10.3892/or.2015. 4353.

[10] G. Fear, S. Komarnytsky, I. Raskin, Protease inhibitors and their peptidomimetic derivatives as potential drugs, Pharmacol. Ther. 113 (2007) 354-368, http://dx. doi.org/10.1016/j.pharmthera.2006.09.001.

[11] J. Villanueva, F. Canals, S. Prat, D. Ludevid, E. Querol, F.X. Avilés, Characterization of the wound-induced metallocarboxypeptidase inhibitor from potato: cDNA sequence, induction of gene expression, subcellular immunolocalization and potential roles of the C-terminal propeptide, FEBS Lett. 440 (1998) 175-182, http://dx.doi. org/10.1016/S0014-5793(98)01447-1.

[12] D. Lufrano, J. Cotabarren, J. Garcia-Pardo, R. Fernandez-Alvarez, O. Tort, S. Tanco, F.X. Avilés, J. Lorenzo, W.D. Obregón, Biochemical characterization of a nove carboxypeptidase inhibitor from a variety of Andean potatoes, Phytochemistry 120 (2015) 36-45, http://dx.doi.org/10.1016/j.phytochem.2015.09.010.

[13] L. Sanglas, F.X. Aviles, R. Huber, F.X. Gomis-Rüth, J.L. Arolas, Mammalian metallopeptidase inhibition at the defense barrier of Ascaris parasite, Proc. Natl. Acad. Sci. U. S. A. 106 (2009) 1743-1747, http://dx.doi.org/10.1073/pnas.0812623106.

[14] D. Reverter, J. Vendrell, F. Canals, J. Horstmann, F.X. Avile, H. Fritz, C.P. Sommerhoff, A carboxypeptidase inhibitor from the medical leech, Hirudo Med. 273 (1998) 32927-32933.

[15] J.L. Arolas, J. Lorenzo, A. Rovira, J. Castellà, F.X. Aviles, C.P. Sommerhoff, A carboxypeptidase inhibitor from the tick Rhipicephalus bursa: isolation, cDNA cloning, recombinant expression, and characterization, J. Biol. Chem. 280 (2005) 3441-3448, http://dx.doi.org/10.1074/jbc.M411086200.

[16] H. Gong, J. Zhou, M. Liao, T. Hatta, T. Harnnoi, R. Umemiya, N. Inoue, X. Xuan, K. Fujisaki, Characterization of a carboxypeptidase inhibitor from the tick Haemaphysalis longicornis, J. Insect Physiol. 53 (2007) 1079-1087, http://dx.doi. org $/ 10.1016 /$ j.jinsphys.2007.06.008.

[17] G. Covaleda, M.A. Del Rivero, M.A. Chavez, F.X. Avilés, D. Reverter, Crystal structure of novel metallocarboxypeptidase inhibitor from marine mollusk Nerita versicolor in complex with human carboxypeptidase A4, J. Biol. Chem. 287 (2012) 9250-9258, http://dx.doi.org/10.1074/jbc.M111.330100.

[18] Q. Liu, L. Yu, J. Gao, Q. Fu, J. Zhang, P. Zhang, J. Chen, S. Zhao, Cloning, tissue expression pattern and genomic organization of latexin, a human homologue of rat carboxypeptidase A inhibitor, Mol. Biol. Rep. 27 (2000) 241-246.

[19] M. Alonso-Del-Rivero, S.A. Trejo, M. Rodríguez De La Vega, Y. González, S. Bronsoms, F. Canals, J. Delfín, J. Diaz, F.X. Aviles, M.A. Chávez, A novel metallocarboxypeptidase-like enzyme from the marine annelid Sabellastarte magnificaa step into the invertebrate world of proteases, FEBS J. 276 (2009) 4875-4890, http://dx.doi.org/10.1111/j.1742-4658.2009.07187.x.

[20] P.F.X. Avilés, R.J. Lorenzo, M. Rodríguez-Vera, M.E. Querol, M.M. Bautista, M.A. Diez, S.C.J.M. Bautista, Therapeutic agents for treatment of malaria, (2008)
https://www.google.com/patents/WO2008077977A1?cl=en.

[21] J. Quilis, D. Meynard, L. Vila, F.X. Avilés, E. Guiderdoni, B. San Segundo, A potato carboxypeptidase inhibitor gene provides pathogen resistance in transgenic rice, Plant Biotechnol. J. 5 (2007) 537-553, http://dx.doi.org/10.1111/j.1467-7652. 2007.00264.x.

[22] J.P. Tam, S. Wang, K.H. Wong, W.L. Tan, Antimicrobial peptides from plants, Pharmaceuticals 8 (2015) 711-757, http://dx.doi.org/10.3390/ph8040711.

[23] M.L. Colgrave, D.J. Craik, Thermal, chemical, and enzymatic stability of the cyclotide kalata B1: the importance of the cyclic cystine knot, Biochemistry 43 (2004) 5965-5975, http://dx.doi.org/10.1021/bi049711q.

[24] M. Werle, K. Kafedjiiski, H. Kolmar, A. Bernkop-Schnürch, Evaluation and improvement of the properties of the novel cystine-knot microprotein McoEeTI for oral administration, Int. J. Pharm. 332 (2007) 72-79, http://dx.doi.org/10.1016/j. ijpharm.2006.09.028.

[25] P.W. Bosland, E.J. Votava, Peppers: Vegetable and Spice Capsicums, C.A.B. International, 2000, http://dx.doi.org/10.1079/9781845938253.0000 ISBN: 9781845938253

[26] N. Antcheva, A. Pintar, A. Patthy, A. Simoncsits, E. Barta, B. Tchorbanov, S. Pongor, Proteins of circularly permuted sequence present within the same organism: the major serine proteinase inhibitor from Capsicum annuum seeds, Protein Sci. 10 (2001) 2280-2290, http://dx.doi.org/10.1110/ps.21701.

[27] S.F.F. Ribeiro, M.S. Silva, M. Da Cunha, A.O. Carvalho, G.B. Dias, G. Rabelo, É.O. Mello, C. Santa-Catarina, R. Rodrigues, V.M. Gomes, Capsicum annuum L. trypsin inhibitor as a template scaffold for new drug development against pathogenic yeast, Antonie van Leeuwenhoek, Int. J. Gen. Mol. Microbiol. 101 (2012) 657-670, http://dx.doi.org/10.1007/s10482-011-9683-x.

[28] V.A. Tamhane, N.P. Chougule, A.P. Giri, A.R. Dixit, M.N. Sainani, V.S. Gupta, In vivo and in vitro effect of Capsicum annum proteinase inhibitors on Helicoverpa armigera gut proteinases, Biochim. Biophys. Acta - Gen. Subj. 1722 (2005) 156-167, http:// dx.doi.org/10.1016/j.bbagen.2004.12.017.

[29] J. Pablo, C. Montes, R.A. Espinosa, J. Luis, M. Sánchez, Purification and Biochemical Characterization of a Protease Inhibitor II Family from Jalapeño Pepper (Capsicum Annuum L), (2014), pp. 661-668, http://dx.doi.org/10.4236/ abb.2014.

[30] W.L. Mock, Y. Liu, D.J. Stanford, Arazoformyl peptide surrogates as spectrophotometric kinetic assay substrates for carboxypeptidase A, Anal. Biochem. 239 (1996) 218-222, http://dx.doi.org/10.1006/abio.1996.0318.

[31] M. Tellechea, J. Garcia-Pardo, J. Cotabarren, D. Lufrano, L. Bakas, F. Avilés, W. Obregon, J. Lorenzo, S. Tanco, Microplate assay to study ccarboxypeptidase A inhibition in Andean potatoes, Bio-Protocol 6 (2016) 1-12, http://dx.doi.org/10. 21769/BioProtoc.2032.

[32] W.D. Obregón, N. Ghiano, M. Tellechea, J.S. Cisneros, C.M. Lazza, L.M.I. López, F.X. Avilés, Detection and characterisation of a new metallocarboxypeptidase in hibitor from Solanum tuberosum cv. Desirèe using proteomic techniques, Food Chem. 133 (2012) 1163-1168, http://dx.doi.org/10.1016/j.foodchem.2011.08. 030 .

[33] H.B. van den Hazel, M.C. Kielland-Brandt, J.R. Winther, Autoactivation of proteinase A initiates activation of yeast vacuolar zymogens, Eur. J. Biochem. 207 (1992) 277-283, http://dx.doi.org/10.1111/j.1432-1033.1992.tb17048.x.

[34] S.O. Sorensen, H.B. Van den Hazel, M.C. Kielland-Brandt, J.R. Winther, pH-dependent processing of yeast procarboxypeptidase $\mathrm{Y}$ by proteinase $\mathrm{A}$ in vivo and in vitro, Eur. J. Biochem. 220 (1994) 19-27, http://dx.doi.org/10.1111/j.1432-1033. 1994.tb18594.x.

[35] E.P. Fischer, H. Holzer, Interaction of proteinases and their inhibitors from yeast. Activation of carboxypeptidase Y, Biochim. Biophys. Acta - Gen. Subj. 6 (1980) 187-198.

[36] J. Brzin, M. Kidrič, Proteinases and their inhibitors in plants: role in normal growth and in response to various stress conditions, Biotechnol. Genet. Eng. Rev. 13 (1996) 421-468, http://dx.doi.org/10.1080/02648725.1996.10647936.

[37] T.J. Ahern, A.M. Klibanov, The mechanisms of irreversible enzyme inactivation at 100C, Science 228 (1985) 1280-1284.

[38] O.R. Damodaran, Amino acids, peptides and proteins, Food Chem. (1996) 322-429.

[39] G.J.J. Broze, T.J. Girard, W.F. Novotny, Regulation of coagulation by a multivalent Kunitz-type inhibitor, Biochemistry 29 (1990) 7539-7546.

[40] V. Vermeirssen, J. Van Camp, W. Verstraete, Bioavailability of angiotensin I converting enzyme inhibitory peptides, Br. J. Nutr. 92 (2004) 357-366.

[41] N. Tobey, W. Heizer, R. Yeh, T.I. Huang, C. Hoffner, Human intestinal brush border peptidases, Gastroenterology 88 (1985) 913-926.

[42] M. Shimizu, Food derived peptides and intestinal functions, Biofactors 21 (2004) 43-47 http://iospress.metapress.com/content/ruv9m8xhdqm48yxk/?genre= article\&issn $=0951-6433 \&$ volume $=21 \&$ issue $=1 \&$ spage $=43$.

[43] B. Hernández-Ledesma, A. Quirós, L. Amigo, I. Recio, Identification of bioactive peptides after digestion of human milk and infant formula with pepsin and pancreatin, Int. Dairy J. 17 (2007) 42-49, http://dx.doi.org/10.1016/j.idairyj.2005.12. 012.

[44] D. Treggiari, G. Zoccatelli, R. Chignola, B. Molesini, P. Minuz, T. Pandolfini, Tomato cystine-knot miniproteins possessing anti-angiogenic activity exhibit in vitro gastrointestinal stability, intestinal absorption and resistance to food industrial processing, Food Chem. 221 (2017) 1346-1353, http://dx.doi.org/10.1016/j. foodchem.2016.11.020.

[45] J.N. Losso, The biochemical and functional food properties of the bowman-birk inhibitor, Crit. Rev. Food Sci. Nutr. 48 (2008) 94-118, http://dx.doi.org/10.1080/ 10408390601177589. 